\title{
Funerary Rites in the Royalist Exile: George Morley's Ministry in Antwerp, 1650-1653
}

\author{
PHILIP MAJOR \\ Birkbeck, University of London
}

Les chercheurs ont récemment porté leur attention davantage sur les exilés royalistes et ont analysé une grande variété d'écrits lä̈cs et dévotionnels contemporains. Il n'y a cependant eu aucun examen approfondi d'un aspect de l'exil, fortement chargé politiquement, qui donne accès aux principaux dispositifs de survie de la résistance royaliste et anglicane surle continent, c'est-à-dire, les rites funéraires. À travers l'analyse de la législation parlementaire et en particulier du ministère de George Morley à Anvers (1650-1653), cet essai tente de saisir les implications de l'utilisation continue par les exilés du Burial Office of the Book of Common Prayer, révélant ainsi dans quelle mesure la subversion royaliste était autant dirigée vers les forces hostiles à l'étranger que dans leur pays.

\section{I}

The burial of royalists on the Continent during the English Revolution has remained a largely uncharted subject, despite the recent resurgence of interest in Royalism and the royalist exile. ${ }^{1}$ This is somewhat surprising, since an examination of its attendant ceremonialism casts new light on our comprehension of royalist resistance in the 1640 s and 1650 s. Moreover, the evidence for such ceremonialism is ample: it is frequently recounted in contemporary royalist sources that the deceased émigré was buried with the full rites of the Church of England, illustrated by two examples from John Evelyn's Diary. In Paris, in October 1649, Evelyn was “at the funeral of one Mr. Downes a sober English Gent, we accompanied his Corps to Charenton, where he was interr'd in a Cabbage-Garden, yet with the Office of our Church, which was said before in our Chappell at Paris." ${ }^{2}$ For the diarist, the relative obscurity of the man buried, and humbleness of his resting place, only cast into bolder relief the implicit sense of gravitas and dignity conferred by the use of Prayer Book ritual. In the same city, in November, 1651, Evelyn discovered the body of the Church of England divine Richard Steward, the former Dean of Westminster, who had followed Prince Charles into exile. Remembering Steward as a "person that besides his particular affection and love to me, was of incomparable parts, and great learning, 
of exemplary life, and a very great loss to the whole Church," Evelyn recalled that "he was buried the next day with all our Churches ceremonies, many noble persons accompanying the Corps." 3 That "all” the Church's ceremonies were employed connotes a reassertion, in straitened circumstances, of ecclesiastical authority, a demonstration to its enemies as well as its adherents not only of the Church of England's continued visibility, but also of its capacity to administer the full range of its sacraments, unfettered by proscriptive English domestic legislation.

The cornerstone of this liturgical proscription was An Ordinance for taking away the Book of Common Prayer, and for establishing and putting in execution of the Directory for the publique worship of God. ${ }^{4}$ Described by one contemporary opponent as a "haplesse Hotch-potch of Impiety,"5 it decreed that "the said Book of Common Prayer be abolished, and the Directory for the Publique Worship of God, herein after mentioned, be established and observed in all the Churches within this Kingdome.” To drive home Parliament's aim of severely circumscribing public use of the Prayer Book, and to ensure the effective promulgation of the Directory, the Ordinance further stipulated that

the said Book of Common Prayer, shall not remain, or be from henceforth used in any Church, Chappel, or place of publique Worship, within the Kingdome of England; And that the Directory for publique Worship herein set forth, shall be henceforth used, pursued, and observed, according to the true intent and meaning of this Ordinance, in all Exercises of the publique Worship of God, in every congregation, Church, Chappel, and place of publique Worship within this Kingdome. ${ }^{6}$

Punishment for contravention of this measure was designed to be progressively punitive: a fine of five pounds for the first offence, ten pounds for the second, and a year's imprisonment for the third. ${ }^{7}$ Any formal use of the Prayer Book-and its associated liturgy and sacraments - in England and Wales during the English Revolution was now effectively illegal.

Significant, if isolated, acts of defiance took place, such as Robert Shirley's building of the Laudian church at Staunton Harold, in 1653. A more nuanced example is that of the essayist and poet, Owen Felltham, who finessed "A form of prayer compos' $d$ for the family of the Right Honourable the countess of Thomond," in which the essential Anglicanism of the Prayer Book was incorporated without explicitly falling foul of the Directory. ${ }^{8}$ The provisions of the Ordinance could not, however, directly impinge on Church of England adherents living overseas. The Prayer Book endured among royalist émigrés, most notably in the chapel of the King's Resident in Paris, Sir Richard Browne, and in the chapel of Edward Hyde, later Earl of Clarendon, in Antwerp. Consequently, in this climate of defeat and 
displacement for crown supporters, it provided a spiritual and, inevitably, political, focal point for royalist resistance.

There is a considerable body of evidence, much of it again found in Evelyn's Diary, for the continued observance by royalist exiles of the full panoply of Church of England services, including those of Holy Communion, christening, marriage, and even the ordination of priests and consecration of bishops. ${ }^{9}$ Yet, while each of these ceremonies played an important role in engendering a sense of cultural continuity amidst the rupture of exile, the rites of burial provide a particularly poignant and recurring motif in the extant contemporary literature. Exile is an extreme environment in which people experience an acute sense of change, and behave in revealing ways. The additional, searching demands placed on exiles by bereavement and grief illuminate their attitudes and responses still further, as well as those of the host communities with whom they live. For this reason, funerary rites in the royalist exile deserve to occupy a more prominent place in the historiography of what Claude Summers has termed "Anglican Survivalism."10 The empowering sense of consolation and subversion derived by royalist exiles from funeral services cannot be underestimated. They provided English émigrés with a constant, shared point of cultural reference in a world turned disharmoniously upside down, a liturgical handrail at moments of despair and incomprehension. As Eva Reimers has argued, "In the context of migration, a funerary ritual ... offers an opportunity to enhance an identity and an origin that is under pressure from the surrounding culture."11 For royalist exiles in Paris, that pressure featured a sedulous attempt by Henrietta Maria to convert the Anglicans among them to Roman Catholicism. As I shall demonstrate, the exiles in the Spanish Netherlands faced equally hostile forces, both from without and from within.

One of the Directory's sub-headings, which also included "Of the Assembling of the Congregation," and "Concerning Publique Solemn Fasting," was "Concerning Burial of the Dead." Unsurprisingly, this section posited that there should be significantly less ceremony than the obsolescent Prayer Book prescribed, commencing with the exclusion of the Church of England practice whereby the priest met the corpse at the church-stile:

When any person departeth this life, let the dead body, upon the day of the Burial, be decently attended from the house to the place appointed for Publique Burial, and there immediately interred without any Ceremony. And because the customes of kneeling down, and praying by, or towards the dead Corps, and other such usages in the place where it lies, before it be carried to Burial, are Superstitious: and for that, praying, reading and singing both in going to, and at the Grave, have been grosly 
abused, are no way beneficial to the dead, and have proved many wayes hurtful to the living, therefore let all such things be laid aside. ${ }^{12}$

Whether a minister of religion was required to be present at the burial appears to have been optional under this new code: “ ... the Minister, as upon other occasions, so at this time, if he be present (my italics), may put them in remembrance of their duty" (p.604).

One of the most robust Church of England defences against this directive was mounted, with characteristically forensic precision, by a pre-eminent Anglican divine of the royalist exile, John Cosin, whose liturgical ministry to the burgeoning community of royalist exiles gathered in Paris, and at other centres of the courtin-exile, during the 1640 s and 1650s, was of key importance. In his Works, which included a withering assessment of Puritan strictures, Cosin referred directly to this passage:

The Puritans, in their profanation, use to tell us that this meeting of the corpse, and going along with it to the grave, or to the church, singing or saying the sentences as we go, is rather a hallowing of the air than any edifying of such as follow the body. ${ }^{13}$

Cosin advanced his counter-argument by invoking biblical paradigms and giving them a sardonic twist. Particular scorn was reserved for the Puritan restrictions on musical accompaniment:

by the same reason King David was much to blame, to carry up the ark into the tabernacle, some going before and some behind, with hymns and songs of glory, and music of all sorts, and all the people following after. If he had consulted with these kind of men, they would have told him though he were never so near to God's own heart, that it was a matter of superstition, and tended to no edification at all. ${ }^{14}$

Alluding to the specific Puritan proscription of singing, Cosin cited the Prayer Book, and in the process affirmed its abiding authority in maintaining that "there be three psalms appointed to be sung, either before or after the burial of the corpse." Focusing next on the priest's casting earth upon the corpse, he drew attention to the perceived redundancy of the minister's role as laid down in the Directory, deploring

that unchristian fancy of the Puritans, that would have no minister bury their dead, but the corpse to be brought to the grave and there put in by the clerk, or some other honest neighbour, and so back again without any more ado. ${ }^{15}$

Cosin's defence of the Prayer Book strengthens the argument that Church of England funerary services on the Continent could express symbolic acts of political rebellion targeted at the republican regime in England. The relationship between 
the twin royalist lodestars of Church and Crown was axiomatically symbiotic, so that a reaffirmation, as here, of the former would invariably be interpreted by contemporaries as a re-avowal of the latter. Moreover, there seems little doubt that the Burial Office of the Prayer Book-to "commend into Thy merciful hands, O Lord, the soul of this our brother N. departed; and ... commit his body to the ground"16 — was lent a politicized inflection by the aberrant circumstances of exile. It is only, perhaps, when we remind ourselves of the eschatological lens through which these rites were viewed that we can achieve a deeper understanding of how charged such events were. To bury someone in exile according to the liturgy of the Church of England was not simply an act of nostalgia, of consolation in defeat, or even of loyalty, though it was all of these things. It was emblematic of the continued existence of an imperilled Church in the ceremonies of the grave, and also, simultaneously, a repudiation of a crucial element in Parliament's attempts to enforce a Puritan religious orthodoxy.

The imperative of ceremonial continuity pervades Cosin's upholding of traditional liturgical conformity in The Works, witnessed by his allusions to the ancient practices of the early Church and its founding fathers. As David Trotter has stated, "Laudian theology encouraged familiarity with the early Church Fathers in order to assert continuity with the pre-Reformation church." 17 The theme of durability was a sword which for royalists had a secular as well as devotional edge. For example, family histories of royalist exiles were imbued at this time with unmistakably political potentialities, instanced in the Memorials of the Holles Family 1493-1656, written in Rotterdam in 1658 by the ardent royalist Gervase Holles. In dedicating his book to his son Frescheville, the author declared dismissively that he was motivated to write the work simply "by my leisure (banished men finde very little business besides writing bookes)"; yet the disingenuousness of this remark is betrayed in the same passage, where Frescheville was assured that in imbibing the contents of the Memorials

\footnotetext{
you shall not only know the names, the qualities, the services and the matches of your ancestors, but in many of them their very features and dispositions ... It is not the least debt ... which we owe unto history that it hath made us acquainted with our dead ancestors and out of the depth and darkness of the earth delivered us their memory and fame. ${ }^{18}$
}

Viewed in the context of Holles's circumstances when composing the work, it is possible to discern a strong sense of royalist partisanship in such sentiments. Imprisoned by Parliament after the siege of Colchester in 1648, Holles was released and allowed to retire to France, eventually settling in Holland, where he was 
"active in promoting the king's return." 19 By accentuating the antiquity of his own family, Holles could implicitly demonstrate a dichotomy between its unquestionable authority - and, by extension, Royalism's as well — and that of the parvenu Commonwealth and Protectorate. To become "acquainted with our dead ancestors" was for Holles not just a paternal piece of advice for his son but a politically loaded comment from within and to the wider royalist community on the perceived transience of the republican regime. Small wonder, then, that for royalist exiles of the 1640 s and 1650 s, even more so than for those in Puritan England, the theme of continuity, which Prayer Book ceremonial embodied, was of such psychological and symbolic moment.

The ministry of the prominent Church of England divine George Morley during his exile in the Spanish Netherlands shines a torch on many of the issues surrounding royalist survival and resistance on the Continent. Formerly chaplain to Charles I, and later attached to the court of Prince Charles, Morley was one of a number of Anglican priests instrumental in sustaining Church of England ceremonies during the exile, notably at Hyde's chapel in Antwerp between 1650 and $1653 .{ }^{20}$ Years after the exile Morley wrote:

For though we were then in Antwerp, where no religion but that of Rome is either professed, or tolerated; yet there I read the Divine Service of our Church twice a day at the canonical hours ... I did there likewise bury the dead and baptise the children according to the form prescribed in our Liturgy, as often as I was desired to do so ... ${ }^{21}$

That Morley performed these rituals "according to the form prescribed in our Liturgy," and deemed this worthy of extended comment, underlines the importance for royalist exiles of liturgical language, of the continued use in their public religious services of the English vernacular. Richard Watson, chaplain to Sir Richard Browne in Paris, illustrates this point in describing, in appropriately Old Testament terms, the English liturgy itself, and not simply the Church's clergy, as having taken flight, and having found safety in Browne's chapel. For Watson, it was the endurance-and concomitant wide resonance-of the liturgy which underpinned the very survival of the English Church:

The public exercise of our liturgy is the Antitype we reflect upon, which, by God's singular indulgence to you, hath, when chased out of the Temple, took refuge in 
your House, so that we have been forced many times to argue from your oratory for a visibility of our Church. ${ }^{22}$

Violent disputes over the Prayer Book, which culminated in the introduction of the Directory, were instrumental in dividing political opinion during the civil conflicts of the 1640 s and beyond. The language of the Book, as much as its subject matter, now played a key practical and symbolic role in both defying Parliament at home and buttressing a shared sense of English religious identity abroad, in a context where, "for Royalists, the authority of the text was in part established by the innately monarchical nature of the English language." ${ }^{23}$ In "Reformed" countries, such as the Dutch Republic, exiles were able to attend services carried out in the vernacular rather than in Latin. In areas of refuge like the Spanish Netherlands and France, however, where the Reformation had not penetrated, and hence where the Church of Rome remained ascendant, Anglican identity was often perceived to be under assault, significantly informing the sense of isolation experienced by royalist exile communities. ${ }^{24}$

The main vehicle for liturgical continuity in exile was the Great Litany, first issued by Cranmer in 1544, and included in all subsequent editions of the Prayer Book. While it drew upon Sarum Rogationtide Litany and Luther's "Latin Litany" (1529), negotiating a typical Anglican via media between the "excessive elaboration" of the one and "unceremonious brevity" of the other, ${ }^{25}$ crucially it was composed in English. Although this deprived the Litany of the advantages enjoyed by Latin liturgical writing, including the effective use of inflections, the advantages of English were widely acknowledged by the exiles, especially in the Prayers and Orders of Service, of which Morley made telling use. As Brook has commented, liturgical composition needs not only "to meet, simultaneously, the workaday but important requirements of ease of articulation and the need to create aural effects of sonority and dignity and rhythmic balance," but also to "give clear expression to profound and subtle thought, ordered into formal shape and pattern." ${ }^{26}$ For Anglicans in exile, no less so than for those who remained in England, the vernacular of the Prayer Book comprehensively achieved this, set against a background where "language, crucially, remained the exile's most immediate link to a lost homeland." 27 Thereby, Anglican services on the Continent, especially funeral services, were infused with a political, "survivalist" ambience which extended well beyond the significance of the specific individual for whom the ceremony was conducted.

Morley went on in the same passage to highlight the variety of Church of England rites he administered at Antwerp. Not only did he "read the divine service of our church twice a day"; he also "celebrated the Sacrament of the Eucharist once a 
month," "did there bury the dead," "baptize children according to the form prescribed in our liturgy," and "besides this did once a week, at least, catechize the whole [Hyde] family wherein I lived, in the principles of Christian doctrine as they are taught in our Church Catechism." In the circumstances of defeat and exile, each of these acts raised political and religious flags; as we have witnessed, Parliament, through the Directory, had banned them all. Moreover, as I have indicated, the regularity and fixity of these public rituals, which included "The Order for Morning and Evening Prayer," brought an important measure of familiarity, structure, and certainty to an often alien and uncertain exilic existence.

Parliament was alive to the activities of Morley and other royalists in Antwerp, evidenced by his signing all but one letter in this period with the pseudonym "Jasper Gower." Travellers to or from the Spanish Netherlands were persuaded to carry letters written by exiles, but as Morley knew full well many of these fell into the hands of vigilant Commonwealth agents. Damagingly for the royalist cause, once this happened such correspondence could, for propaganda purposes, be published in Parliamentarian newspapers. Such a fate befell a message written from Antwerp on 8 February 1650, by William Cavendish, later first Duke of Newcastle, which concluded with the urgent but evidently unexecuted instruction, "pray burn this letter." 28

Anglican resistance in exile, however, was not simply directed against Parliament. Morley's recollection that in Antwerp "no religion but that of Rome is either professed, or tolerated" signals the difficulties encountered by English exiles in their immediate environment. That is, even if exiles remained unaffected by the Directory, the use of Church of England rites in Flanders was not as straightforward as in other parts of Europe, like France. There, royalist and Anglican exiles were able to enjoy a reasonably untrammelled confessional existence, secure in the (albeit tacit) support of the French court, at least until the court-in-exile was forced to leave in 1654. Morley's ministry at Antwerp was conducted in a Flemish city with its own distinct cultural traditions, in a geopolitically combustible region of Europe where military and religious allegiances were regularly shifting. Important questions arise concerning how royalist exiles adapted to their new surroundings, and, conversely, the attitude of the Habsburg authorities to the activities of Morley.

Antwerp, it should be said, was by no means an entirely uncongenial sanctuary for royalist exiles. It is true that, unlike The Hague, which in the early 1650 s could boast two royal courts (those of Mary of Orange and Elizabeth of Bohemia), it did not have the attraction of being near to the exiled court, at least until April 1656, when Prince Charles moved first to Bruges and then to Brussels. Nevertheless, it 
had several significant advantages. From the early 1640 s a number of royalist exiles chose to make Antwerp their home. Its close proximity to England, and longestablished English merchant community, were two reasons for this. Moreover the city was widely reputed for its conviviality. ${ }^{29}$ Evelyn, as much a tourist as an exile, was particularly impressed, as attested by a diary entry he made in 1641: "In short I think no city in Europe exceeds Antwerp for Elegancy, quiet, civil inhabitants, plenty \& all one need wish for of pleasure \& convenience.” For Evelyn, Antwerp was "one of the sweetest places in Europe ... nor did I ever observe a more quiet, clean, elegantly built, and civil place than this magnificent and famous city." William Cavendish, one of Antwerp's most senior English émigrés, was equally enamoured of the city; in 1649 he described its citizens as "the civilest and best-behaved people that ever I saw." 30

There were tangible economic advantages for royalist exiles, too. Most royalists in Antwerp, and in other cities in Flanders, such as Bruges, Ghent and Brussels, were exempt from paying tax and excise duties, though this did not necessarily prevent periods of grinding poverty: Morley at one point lent the Hyde family twenty pounds to make ends meet. ${ }^{31}$ At an ambassadorial level, additional courtesies were extended to royalists. On his arrival in Antwerp in 1649, and again on his return, following his embassy to Madrid in 1650-1651, Hyde received permission from Philip IV to "reside anywhere in those provinces he best liked, until he could conveniently repair to the king his master; and in the meantime enjoy all the privileges due to an ambassador." On both occasions, Archduke Leopold William, Captain-General and Governor General of the Spanish Netherlands, granted Hyde an audience in Brussels, in which he confirmed that the wishes of his uncle, Philip, would be honoured. "He spake in Latin," Hyde wrote of himself in the third person, "and the archduke, answering in the same, assured him of all the respects he could pay him whilst he stayed in those parts: and thereupon he went to his family in Antwerp."32

Notwithstanding such diplomatic civility, Morley's ministry in Antwerp coincided with an awkward period in relations between the Habsburg government and English exiles in Flanders. Sixteen fifty-three, the final year of his ministry, was still three years before the Treaty of Brussels, which bound Charles and Philip IV to the common goal, over the next two years, of planning for Spanish and English forces to attack England, with Spain promised the return of Jamaica and the suspension of penal laws against Catholics in England. While Philip was swift to condemn the execution of Charles I in January 1649, by November 1650 political expediency saw him contemplate an alliance with republican England against the French, with whom Spain had been at war since 1635. Accordingly, 
in January 1651 Philip publicly recognized the English Commonwealth, the first European monarch to do so.

A pertinent example of this fluid pattern of alliance-building was played out during Hyde's embassy to Spain, undertaken to raise funds for Prince Charles. Hyde and his companion, Francis Cottington, to their increasing agitation, were kept waiting for days in San Sebastian, on the Basque coast, while the Spanish ambassador in London, Don Alonso de Cardenas, warned his government about the political and military might of the nascent English republic. Once finally at Madrid, the appearance of a Parliamentarian squadron of ships outside Cartagena, followed by the murder of the government's representative at Madrid, Anthony Ascham, by royalist assassins, led to frantic diplomatic manoeuvring by the Spanish to offend neither their royalist nor Parliamentarian English guests. The Habsburg government hedged its bets, balancing its instinctive support for the English Crown with the political pragmatism of appeasing a powerful new regime. Hyde was left frustrated, remarking darkly that the Spanish "promise us money, but they are a wretched people, without honour or courage, and I doubt not but their friends, the Parliament, will use them accordingly." 33

\section{III}

In the area of religion, however, in an almost exclusively Catholic Antwerp, the difficulties faced by English exiles in the Spanish Netherlands are brought into sharper focus. It should be acknowledged that at an official, diplomatic level, Morley, through his association with Hyde, appears to have remained unmolested in performing his ministry. As well as granting Hyde the freedom to live where he wished, Philip and Leopold William gave him "the freedom of his chapel, not only for his own devotions, but for the resort of all the Protestants who were then in the town." 34 This seems to have been a consistent policy on the part of the Habsburgs: Sir Henry de Vic, the King's Resident in Brussels, kept a similar chapel in Brussels, which was also granted oratory status by Archduke Leopold, and which proved equally popular among the exiles of that city. 35

However, in one respect the very fact that such diplomatic privilege was necessary betrays the hostile religious landscape in which the exiles' Anglican worship took place. Catholicism was a fundamental aspect of life in the Spanish Netherlands of the mid-seventeenth century. At a time when the Counter-Reformation was at its height, the new sense of identity in a society still emerging from civil war was largely based on shared Catholic ties. Indeed, Calvinism had almost completely 
disappeared in the southern Netherlands by 1648, along with all other forms of Protestantism. ${ }^{36}$ Catholicism was especially dominant throughout the 35 parishes of Antwerp, where, manifested in the city's copious shrines and images of saints on the banks of the River Scheldt, it rendered the visual and social environment markedly divergent from that of the post-Reformation England known to the exiles. ${ }^{37}$ Archduke Leopold William himself, like archdukes before him, had in his state entry into Antwerp, in March 1648, been welcomed with sumptuous Catholic pageantry, befitting a man who was not only a military figure but also a bishop of five cities..$^{38}$ The rural deanery of Antwerp alone boasted twelve pilgrimage sites; priests, especially Jesuits, often published lives of regional saints and vernacular histories of local pilgrimages. Religious chapters were numerous: the Englishman John Berry, in 1649, noted the preponderance in Antwerp of "Augustines, Dominicans, Carmalites, Franciscans, Capuchin Franciscans" and Jesuits, together with fifteen other religious fraternities. ${ }^{39}$ Furthermore, by 1650 there was almost universal conformity with the obligation to attend Sunday Mass. Clearly, the freedoms enjoyed in the city in the previous century by such luminaries of the English Reformation as William Tyndale, Simon Fish, and Richard Bayfield no longer applied in the 1650s; indeed, it was not until the nineteenth century that the Anglican community in Antwerp once more had its own parish church, the Chappelle des Tanneurs. ${ }^{\circ}$ The significant differences between the exiles' experience in France and the Spanish Netherlands can in part be explained by the force of the Edict of Nantes, issued by Henri IV in 1598 primarily to end the long-running French Wars of Religion, and not revoked until 1685. Though it did not apply to Paris, the religious rights the Edict gave to French Protestants informed the climate of tolerance towards the exiles. By contrast, Protestant subjects in the Spanish Netherlands enjoyed no such liberties.

Given this context - an Antwerp where, as Morley recalled, "no religion but that of Rome is either professed or tolerated"-it is perhaps not surprising that, whatever the official policy of the Habsburg government, freedom of worship for royalist exiles was not universally welcomed by the local Catholic populace. Indeed, on occasion the opposition to Protestants was openly antagonistic. For example, the Church of England divine Richard Watson recorded that: "I remember when I was in Flanders, an old Benedictine asking me how I liked the decency of their churches, and solemnity of their service, or public worship." Watson related how he demurred, and then recalled how "the Benedictine somewhat sarcastically replied that, in Archbishop Laud's time indeed, your church washed and beautified her face a little; but for all that, more intrinsically she was a very slut." ${ }^{41}$ Morley himself came face to face with Catholic conflict while debating the respective histories and 
doctrines of the Church of England and the Church of Rome with Father Darcy, at the Jesuit College in Brussels, though at least on this occasion "the conference began and ended with all Civility on both parts." 42

The retention and assertion of a continued Church of England identity in Antwerp were therefore as much in contradistinction to the prevailing Catholic milieu in Flanders as to the Puritan authorities at home in England. Indeed, it was a badge of honour for Morley that he resisted all temptations to engage in the religion of his hosts:

Nor ever was I so much as once present at a Mass, nor kneeled at the Exposition or meeting of the Host, whilst I was in the Popish countries; though I was many times threatened to be complain'd of, to the Bishop of Antwerp, by the English Papists that were there, and especially by those that were Apostates from our Church; but I believe my living in Sir Edward Hyde's House was my protection. ${ }^{43}$

Hyde verified the local Catholic resentment identified by Morley: "the English and Irish priests and all the Roman Catholics of those nations exceedingly murmured at" Leopold granting him an ambassador's oratory in Antwerp, "and used all the endeavours they could to have [it] taken away, though in vain."44

It is in recording the circumstances of one particular Anglican funeral service which he presided over in Antwerp, however, that Morley reveals most tellingly how, for all the good offices of the Archduke, local Catholic sensitivities could have a significantly deleterious impact on the practising of Church of England ritual. In performing such services according to "the form prescribed in our liturgy," Morley recalls that it was necessary to do so "privately in the House ... where the Party that died was to be buried.” In this fashion he recollects that he

buried Mr Mungo Murrey, a Gentleman of Quality, and One of the Kings Servants, reading the Office of Burial prescribed by our church, and using all the Formalities required by that Office ... After which ... The Body was at Midnight conveyed to a poor Cloyster, and there Interr'd, as the Bodies of other Protestants that died there were also; which was a favour easily and usually obtained for a little Money. ${ }^{45}$

As this passage shows, as soon as Morley was outside of Hyde's officially sanctioned oratory, which in itself only allowed for private services, he was exposed to the constraint of interring the deceased person under the cover of nightfall. Bribery of the grave attendants was necessary, since non-Catholics should not have been buried in consecrated ground. Elsewhere, where their burial sites have been established with any certainty, Anglican exiles were interred in Protestant cemeteries or churches within or near the city of refuge, like Sir John Suckling and "Mr Downes" in Paris, and Catholics were laid to rest in Catholic churches, like 
Richard Crashawe in Rome. In Flanders, Catholics could be buried in English Jesuit colleges, such as Sir Toby Matthew in the chapel crypt of the college at Ghent. ${ }^{46}$ By marked contrast, the options for Anglicans in Flanders were limited. Henry Wilmot, first Earl of Rochester, died in Ghent, but his body was transferred to, and, until the Restoration, kept embalmed in, the Dutch (and hence Protestant) port of Helvoetsluys, placed "with what decency we could, and as little noise," next to the body of Sir Ralph Hopton, who had died in Bruges. ${ }^{47}$ Anomalies remain: the Anglican Sir Richard Grenville, for example, "the King's general in the West," was reportedly buried in a church in Catholic Ghent, though no evidence for this has been found. Nevertheless, the overall impression gained from the extant sources is that Protestant burial in the Spanish Netherlands during the 1650 s was fraught with difficulty, and, where possible, to be avoided.

Such enforced furtiveness as that displayed in the burial of Mungo Murray doubtless elicited at least two main responses from exiled Anglicans. First, a sober realization that the full majesty, as they perceived it, of Church of England ceremony had by necessity to be compromised in order to be performed at all; and second, a sustaining sense of unity in adversity. In these exilic circumstances, the collective, grim determination to perpetuate the observance of Church of England rites, especially those of burial, was for royalists not only a powerfully symbolic means of demonstrating resistance to the English Parliament. It was also a way of asserting their own traditional religious culture, in the vernacular, in a locale where the dominant faith, in Flanders more so than in France, was neither Anglicanism, nor even another form of Protestantism, but Roman Catholicism. Moreover, this royalist and Anglican self-assertion nurtured implications of a longer-term political, as well as religious, nature. Since the Church of England was held by the exiles to remain intact, uncontaminated, as they saw it, by the conspicuous Catholicism of its new location on the Continent, so too was monarchy itself regarded as undefiled and unbroken, and thus, like the Church, not only able but also fit to be restored to England, as and when circumstances allowed. ${ }^{48}$

In conclusion, this essay has shown that an exploration of Anglican funerary rites in the royalist exile contributes to an improved understanding of the continuity of English religious identity during the English Revolution. It suggests that funeral ceremonies in exile were invested with meaning on both a religious and a political level. At a time when the Anglican Church and royalist cause seemed to be teetering close to oblivion, these services demonstrated the continuity of Prayer Book usage, in defiance both of Puritan legislation in England and local hostility in the place of exile, particularly in staunchly Catholic Flanders. In the context of defeat and 
displacement the liturgical language of the Prayer Book, crucially in the vernacular, endowed such occasions with a sense of community, consolation, and subversion. Finally, while concerned specifically with burial services, a focus justified by the peculiar poignancy attached to death in exile, this study also serves as an argument for closer scrutiny of other Church of England ceremonies preserved on the Continent, each of which had its own religious and political ramifications.

\section{Notes}

1. A resurgence evidenced, notably, by Geoffrey Smith, The Cavaliers in Exile, 1640-1660 (Basingstoke: Palgrave, 2003); Jerome De Groot, Royalist Identities (Basingstoke: Palgrave, 2004); Robert Wilcher, The Writing of Royalism, 1628-1660 (Cambridge: Cambridge University Press, 2001); Christopher D'Addario, Exile and Journey in Seventeenth-Century Literature (Cambridge: Cambridge University Press, 2007); and Royalists and Royalism during the English Civil Wars, ed. Jason McElligott and David L. Smith (Cambridge: Cambridge University Press, 2007). I am grateful to the anonymous reviewers of the original draft of this essay for their helpful comments and suggestions.

2. John Evelyn, The Diary of John Evelyn, ed. E. S. de Beer, 6 vols. (Oxford: Clarendon Press, 1955), vol. 2, p. 565 .

3. Evelyn, Diary, vol.3, p. 49.

4. Acts and Ordinances of the Interrregnum, ed. C. H. Firth, R. S. Rait, 3 vols. (London: HMSO, 1911), vol. 1, p. 582 .

5. Mercurius Elencticus, 17/5/48-24/5/48, Thomason Tracts, British Library, E. 443 (45).

6. Acts and Ordinances, vol. 1, pp. 582-83.

7. Acts and Ordinances, vol. 1, pp. 582-83.

8. R. Lacy, "Sir Robert Shirley and the English Revolution in Leicestershire," Transcriptions of the Leicestershire Archaeological and Historical Society 58 (1982-83) 25-35; Dictionary of National Biography (2004).

9. Evelyn, Diary, vol.2, pp. 564, 567, 536; vol.3, p. 633.

10. Claude J. Summers, “Tears for Herrick's Church,” George Herbert Journal 14 (Fall 1990-Spring 1991), pp. 51-71, p. 52.

11. Eva Reimers, "Death and Identity: graves and funerals as cultural communication," Mortality 4 (2) no. 2 (July 1999), pp. 147-66, p. 149.

12. Acts and Ordinances, vol. 1, p. 604.

13. John Cosin, The Works of the Right Reverend Father in God John Cosin, Lord Bishop of Durham, ed. J. Sansom, 5 vols (Oxford: John Henry Parker, 1843-55), vol. 5, p. 165.

14. Cosin, p. 165 .

15. Cosin, p. 167-68.

16. Cosin, p. 497. 
17. David Trotter, The Poetry of Abraham Cowley (Basingstoke and London: Palgrave MacMillan, 1979), p. 68.

18. Gervase Holles, Memorials of the Holles Family 1493-1656, ed. A. C. Wood (London: Camden Third Series, 1937), vol. 55, p. 2.

19. Dictionary of National Biography (1908).

20. Morley was also active in exile circles in The Hague, Cologne, Bruges and Breda. See F. Bussby, "An Anglican in Exile," Church Quarterly Review 166 (1965), pp. 426-38.

21. Bussby, p. 432.

22. John Evelyn, The Miscellaneous Writings of John Evelyn, ed. W. Upcott (London: 1825), p. $506 \mathrm{fn}$.

23. De Groot, p. 63 .

24. It is interesting to note the contrast in attitudes between the English exiles in the mid-seventeenth century with respect to the use of the Book of Common Prayer and those who fled Queen Mary a century earlier. The latter were uniformly welcomed by Protestants in Europe, but as the Troubles in Frankfort showed, they were not uniformly committed to using English forms of worship while abroad.

25. G. J. Cumming, A History of Anglican Liturgy (London: MacMillan, 1969), p. 90.

26. S. Brook, The Language of the Book of Common Prayer (London: Andre Deutsch Ltd, 1965), p. 122.

27. D’Addario, p. 4.

28. Margaret Cavendish, The Life of William Cavendish, Duke of Newcastle, ed. C. H. Firth (London: Routledge, 1886, repr. 1907), p. 205.

29. Lisa Jardine, Going Dutch: How England Plundered Holland's Glory (London: Harper, 2008), pp. $175^{-77}$.

30. Evelyn, Diary, vol. 1, p. 45; vol. 2, p. 67; Cavendish, p. 51.

31. Bussby, p. 431.

32. Edward Hyde, first Earl of Clarendon, The Life of Edward Earl of Clarendon, Lord High Chancellor of England, 3 vols. (Oxford: Clarendon Press, 1857), vol. 1, pp. 282-83.

33. Hyde, vol. 1, p. 362.

34. Hyde, vol. 1, p. 283.

35. Bishop John Bramhall recorded that de Vic was "preaching constantly every Sunday, and frequently administering the Sacrament [and confirming such as desired it]. The English merchants of Antwerp, ten leagues thence, used to be monthly of his audience and communion, and were his best benefactors," in J. Bramhall, The Works of the most Reverend Father in God, John Bramhall ... With a life of the author, and a collection of his letters, 5 vols. (London: John Henry Parker, 1842), vol. 1, p. x.

36. Charles Ralph Boxer, The Dutch Seaborne Empire 1600-180o (London: Hutchinson, 1965), p. 4.

37. James D. Tracy, "With and Without the Counter-Reformation: The Catholic Church in the Spanish Netherlands and the Dutch Republic, 1580-1650," The Catholic Historical Review (October 1985), pp. 547-75 (p. 557). 
38. Leopold was glorified by the Chapter of Antwerp Cathedral in two large paintings placed in front of the church door. H. Vlieghe, "The Decorations for Archduke Leopold William's State Entry into Antwerp," Journal of the Warburg and Courthauld Institutes (1976) vol. 39, pp. 190-98.

39. C. D. Van Strien, "Recusant Houses in the Southern Netherlands as seen by British Tourists, c.1650-1720," Recusant History 20.4 (October 1991), pp. 495-511 (p. 496).

40. Sarah Baines, A History of the English Church in Antwerp (London: The Church, 1962), pp. 21-22. Protestant freedoms in Antwerp in the sixteenth century were, it should be remembered, far from absolute. In 1535 the Antwerp authorities seized Tyndale on the grounds of his alleged heresy. Following imprisonment and a trial, he was strangled and burned at the stake in Brussels in 1536.

41. R. S. Bosher, The Making of the Restoration Settlement: the influence of the Laudians, 1649-1662 (London: Dacre Press, 1951), p. 59.

42. George Morley, The Sum of a Short Conference betwixt Father Darcy and Doctor Morley at Bruxelles (London: 1683), p. 8.

43. George Morley, Several Treatises written upon Several Occasions, 5 vols. (London: 1683), vol. 5, p. ii.

44. Bosher, p. 59.

45. Morley, Several Treatises, vol. 5, p. ii.

46. Oxford Dictionary of National Biography (2004).

47. Calendar of State Papers Domestic, 1658, p. 297, 300; Oxford DNB (2004).

48. Restoration panegyrists commonly twinned the survival of the Church of England with that of Prince Charles. Dryden's “To His Sacred Majesty, A Panegyric on his Coronation" (1661), for example, avers "How justly from the church that crown is due / Preserved from ruin and restored by you!” The Poems of John Dryden, ed. Paul Hammond, 5 vols. (London: Longmans, 1995), vol. 1, p. 57, lines 47-48. 